TAPROBANICA, ISSN 1800-427X. April, 2012. Vol. 04, No. 01: pp. 27-36, 1 pl.

(C) Taprobanica Private Limited, Jl. Kuricang 18 Gd.9 No.47, Ciputat 15412, Tangerang, Indonesia.

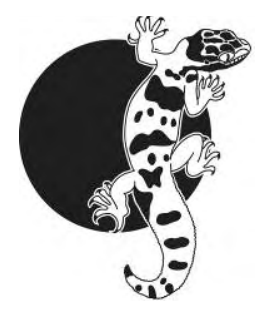

\title{
A REVIEW OF THE DISTRIBUTION OF BATS IN SOUTHWESTERN REGION OF DECCAN, MAHARASHTRA - INDIA AND CONSERVATION RECOMMENDATIONS
}

Sectional Editor: Colin Chapman

Submitted: 06 September 2011, Accepted: 23 May 2012

\author{
Mahesh C. Gaikwad ${ }^{1}$, Sujit S. Narwade ${ }^{2}$, Kamlakar M. Fartade ${ }^{3}$ and Vishakha S. Korad ${ }^{4}$ \\ ${ }^{1}$ Nimblak, Faltan, District Satara, Maharashtra, India \\ ${ }^{2}$ Utkarsh Nagar, Vijapur road, Solapur, India; E-mail: sujitsnarwade@gmail.com \\ ${ }^{3}$ At post Satwaiwadi, Tal-Vashi, District Osmanabad, Maharashtra, India \\ ${ }^{4}$ Department of Zoology, Fergusson College, Pune, Maharashtra, India
}

\begin{abstract}
In present survey carried out in the South-West region of Maharashtra, India, 11 bat species were reported from the study area. The area comprised four districts of Maharashtra namely Pune, Satara, Solapur and Osmanabad. It was also found that all the bat species mentioned in this paper are much more widely distributed than was previously recorded and populations occur in areas for which only single or scattered records were previously available. Conversion of habitats of bats for various purposes by humans was found as one of the important threats to bats in region.
\end{abstract}

Keywords: Chiroptera, fruit bat, leaf-nosed bat, false vampire, flying fox, Pipistrelle, ecology.

\section{Introduction}

Bats form some of the largest non-human aggregations of mammals, and may be among the most abundant groups of mammals when measured in numbers of individuals. Among the mammals of the world, bats comprise 25\% (Mickleburgh et al., 2002). The Megachiroptera includes fruit bats and flying foxes of the tropical forests (Hill \& Smith, 1984), Megachiropterans have a claw on the second finger of the wing. They have longer muzzles than micro-chiropterans and, while a few species can navigate by echolocation, fruit bats generally navigate by sight and have large, light-sensitive eyes. Most fruit bats are helpless in total darkness but can see very well in dim light. About 97 species of Microchiropteran bats found in India are insectivorous. They are important components of forest as well as agricultural ecosystems. They consume insects in large volumes up to $100 \%$ of their body weight per night (Davison \& Zubaid, 1992; Eckrich \& Neuweiler, 1988; Kunz, 1982; Rainey \& Pierson, 1992).

The bat fauna has been well studied in the Western Ghats and parts of Marathwada (especially Aurangabad and Nanded districts) region of Maharashtra (Brosset, 1962a,b,c,d; Gaikwad, 2007; Korad \& Gaikwad, 2006; Korad et al., 2007; Wroughton, 1912; 1913a,b,c, 1916a,b,c). Most of 
the reports published in the early $20^{\text {th }}$ century are restricted to bat species reported along with other mammals of the region. Nevertheless, information for many species was based only on museum or literature references, with very little information on population or distribution patterns (Molur et al., 2002). Our main objective was to understand the distribution of bat species in South-West Maharashtra.

\section{Materials and Methods}

Study area: The study area, the Deccan region of South-West Maharashtra, India includes semi arid forest, open scrublands, and southern tropical thorn forest (Champion \& Seth 1968). It lies at an average of $600 \mathrm{~m}$ above sea level and receives low rainfall, with about $600 \mathrm{~mm}$ annual precipitation. Our surveys covered the majority of the areas from four districts, namely Solapur, Osmanabad and parts of Pune and Satara districts of Maharashtra (Plate 2).

Data collection: Five hundred specimens were collected during a previous project 'Assessment of bat diversity in the Central Western Ghats of Maharashtra', funded by Ministry of Environment and Forests at Fergusson college, Pune, India, during 2002-05. These specimens were used as reference material for identification of the bat species during the present study. Measurements were taken for the opportunistically found dead, injured or rescued bats over the study period. First survey in study area was carried out in summer 2004 and subsequent study was undertaken in 2008. Selected areas were revisited in June 2011, when bats were typically found in large colonies, avoiding winter hibernation and the breeding season. Identification of the bat roosts in study area was also based on the information collected from local people and field visits were arranged accordingly. Initial site assessment was done at less disturbed areas by humans and also at other potential bat areas, such as large trees, temples, forts, and old buildings. Bat signs such as droppings, urine stains along with cracks, holes and crevices were also observed.

The population of small bat colonies was recorded by direct count (Swift, 1980). Large colonies were visited at the time of emergence of bats and counting was done by snap shot method (observing bats at a particular moment) and noting down the time period required by the bats for leaving the roosting site (Hallam et al., 2010). In the majority of the cases the bats were found in crevices at least $5 \mathrm{~m}$ above the ground, on roofs and walls. Most were identifiable at some distance. It was known that colonies of other cliff crevice dwelling vertebrates such as white-throated swift, Aeronautes saxatalis were found in vicinity to bat colonies (Pierson \& Rainey, 1998). House swifts Apus affinis are also known to inhabit old buildings, temples, forts, etc. in India. Therefore, based on earlier experience we refined our survey method and selected comparatively undisturbed areas, where house swifts Apus affinis can easily been observed flying. We got good results and could find out more than $30 \%$ of our bat roosts with help of this method. Bat identification follows Srinivasulu et al. (2010) and Bates \& Harrison (1997).

\section{Results}

Species specific information about earlier records (Bates \& Harrison, 1997, Molur et al., 2002) has been given along with a map to highlight the previously reported sites of the bats in Maharashtra, relative to the results of the present study. Mapping of the colony sites was done for understanding distribution of bats in the study area. Identification keys such as dental formula of the bat species which are difficult to identify without measurements have been provided for selected cases.

\section{Fulvous Fruit Bat (Fig. 1) Rousettus leschenaultii}

This species is a medium sized bat and can be recognized by its large claw on first digit and a smaller one on the second, a short tail and rostrum of the skull moderately elongated. The muzzle is heavy and has deep emargination between projecting nostrils. The $2^{\text {nd }}$ phalanx of the $3^{\text {rd }}$ metacarpal is smaller than in $R$. aegyptiacus. This bat was observed in large, underground water tunnels of more than one $500 \mathrm{~m}$ length. Colonies of more than 15,000 was observed at Naldurga and Paranda forts while alongside roads at Nimblak, Mangalwedha and Kegaon their population was found to be between 5000 and 10000 individuals. We found that the population of this bat species was associated with the age of tunnel, which means recently developed tunnel holds comparatively fewer individuals.

Locations: Nimblak-Phaltan; Mangalvedha; Kegaon road; Naldurga Fort; Paranda Fort.

Previous records from Maharashtra: Ghatmatha (Wroughton, 1916b); Jogeshwari; Kanehri; Elephanta; Alibag; Khopoli; Khandala; Ratnagiri; Aurangabad; Chikaldara (Brosset, 1962a); Mulshi; Mahabaleshwar; Wai, Satara; Bhor, Pune; Shivneri 
Fort, Junnar; Malshej Waterfall, Lonavala (Gaikwad, 2007).

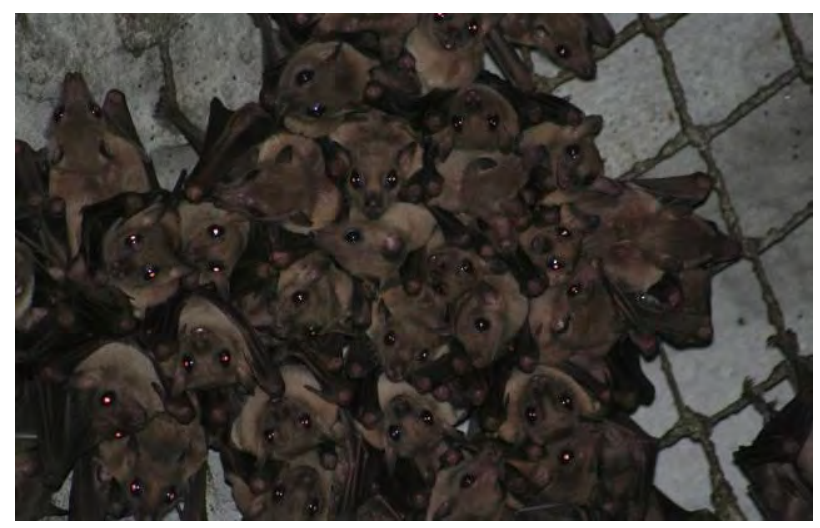

Figure 1: Rousettus leschenaultii

\section{Indian Flying Fox (Fig. 2) \\ Pteropus giganteus}

This species is a medium to large sized fruit bat without a tail. The patagium arises from sides of the dorsum and back of the $2^{\text {nd }}$ toe. Its ventral surface was pale tan to deep orange or chestnut brown. It is one of the common species in Maharashtra, but its roosting areas were not previously recorded from the study area. During our study we observed 16 colonies of $P$. giganteus, numbering between 100 and 500 individuals. Bat colonies were found roosting large old trees such as figs (Ficus sp.), mango (Mangifera indica) and tamarind (Tamarindus indica). Flying foxes were observed dispersing several kilometres from their roosting site for foraging.

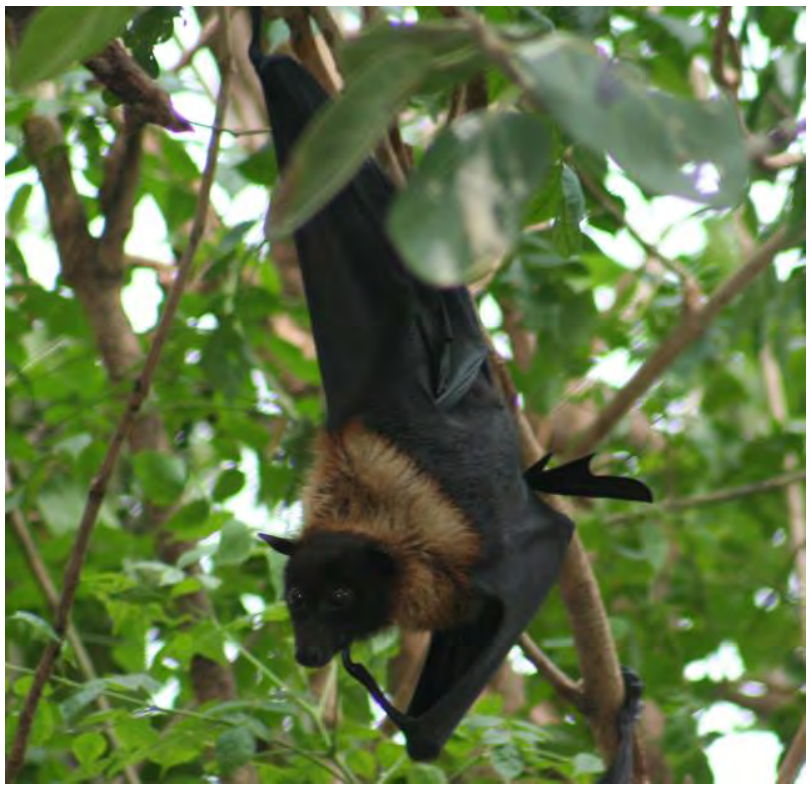

Figure 2: Pteropus giganteus
Locations: Natepute; Akluj; Malinagar; Maloli; Bhalvani, Pandharpur; Rambaug, Pandharpur; Tembhurni; Karmala; Barshi; Pangaon; Solapur city; Kati; Sindfal; Kini; Jagji; Mangalvedha.

Previous records from Maharashtra: Rajwadi, Patan; Pili Sipna Valley (Wroughton, 1912); Panshet backwater, Pune (Wroughton \& Davidson, 1920a); Mumbai, Malad; Kalyan; Thane, Belapur; Ahmednagar (McCann, 1934); Near Umbraj, Satara; Nagpur; Amraoti (Moghe, 1951); Chanda; Pune (Korad \& Yardi, 1998-2001).

\section{Short-nosed Fruit bat (Fig. 3) Cynopterus sphinx}

This species is a small sized fruit bat with a short tail (half enclosed within the interfemoral membrane). Both the first and second fingers have distinct claws. Cynopterus sphinx has larger ears with paler anterior and posterior borders than its close relative $C$. brachyotis. This bat species was recorded from all over the study area and observed roosting at day time in groups of 4-20, mainly on trees like Ashoka (Polyalthia longifolia). In the late evening, bats were found in greater numbers, foraging on nearby fruiting trees. In some areas these bats were found dead on metal fences of vineyards.

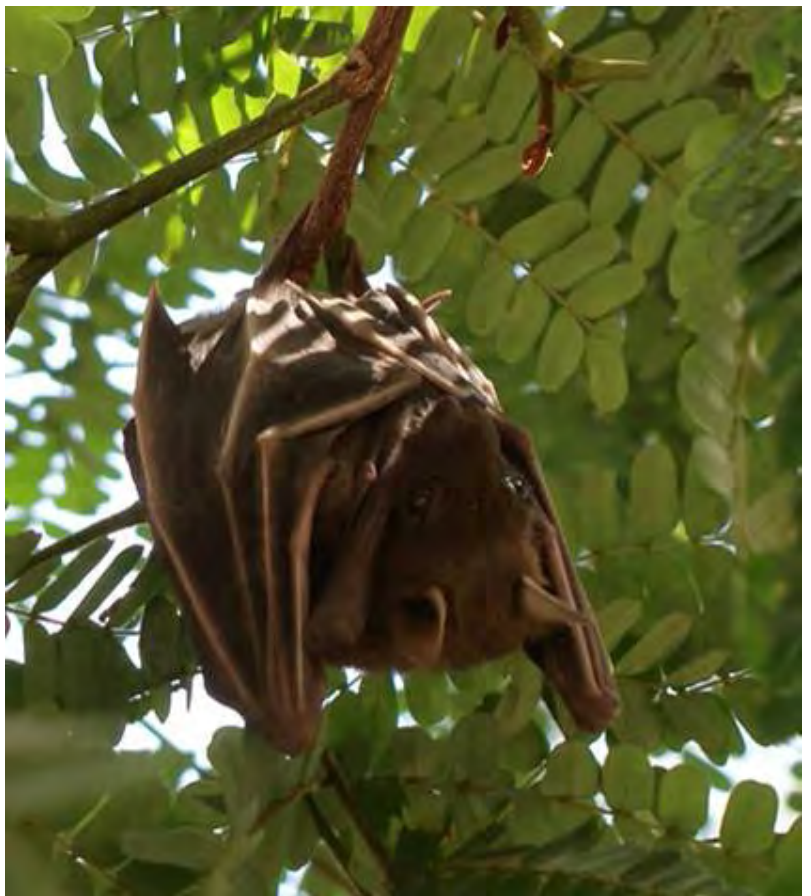

Figure 3: Cynopterus sphinx

Locations: Supe; Patas; Daund; Nimblak; Baramati; Natepute; Indapur; Karmala; Nira Narsingpur; Malshiras; Malinagar; Tembhurni; Maloli; Bhalavani, Pandharpur; Mangalvedha; 
Solapur; Kati; Pangaon; Barshi; Kini; Jagji; Osmanabad.

Previous records from Maharashtra: BandraMumbai; Nashik; Chanda (Wroughton, 1913a); Pune (Wroughton \& Davidson, 1920a); Nagpur (Das \& Sinha, 1971; Korad \& Yardi, 1998-2001); Junnar; Bhor; Purandar; Saswad; Mulshi; Malshej (Gaikwad, 2007); Lonar (Joshi, In Molur et al., 2002).

\section{Greater Mouse-tailed Bat (Fig. 4) Rhinopoma microphyllum}

This bat species can easily be recognized by a tail that is generally shorter than the forearm. The face, ears and connecting membrane on the forehead are all without fur; the chin is also largely devoid of hair. Dermal ridge is poorly developed and condylocanine length (CCL) and mandibular toothrow (CM3) are longer and nasal inflations are smaller than other Rhinopoma species. Colonies of 50-100 bats were found at Naldurga Fort and an old temple in Apsinga village of Osmanabad district.

Locations: Apsinga, Tuljapur; Naldurga Fort.

Previous records from Maharashtra: Bombay (Hill, 1976); Nagpur (Sinha, 1970); Osmanabad; Songir, Bhamer (BMNH)

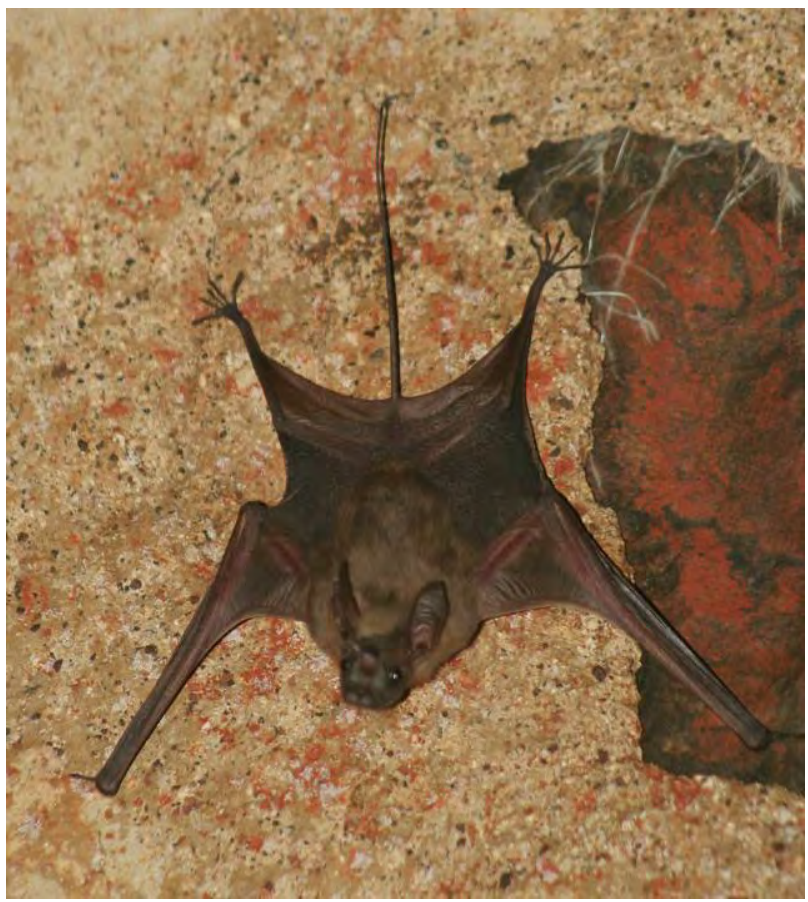

Figure 4: Rhinopoma microphyllum

\section{Long-winged Tomb bat (Fig. 5) Taphozous longimanus}

This species is a small medium sized sheath-tailed bat, with a semicircular gular sac on the throat. Each ear has a tragus with a club-shaped extremity.
The wing is attached to the ankle, and the abdomen is hairy. The tail is enclosed in an interfemoral membrane and the tail tip projects from the upper surface of the membrane at about the midpoint. The wings are long and narrow, and the second digit has no phalanges. The forearm length (FA) is about 60 $\mathrm{mm}$; the third metacarpal is almost equal in length i.e. almost $95.9 \%$ to $98.83 \%$ of FA. The condylocanine length of the skull is about $20 \mathrm{~mm}$. Colonies typically have a strong smell. It is one of the cave dwelling bats observed in small groups of 10-12, at six areas such as Patas, Naldurga, (fort), Solapur (Old spinning mill premises), Old monument (Apsinga) and Buddhist Cave (Osmanabad), Cerivces of old temple wall (Dhamangaon).

Locations: Patas; Dhamangaon, Solapur; Osmanabad caves; Apsinga; Naldurga.

Previous records from Maharashtra: Arnala (Brosset 1962a); Bandra, Mumbai; Chanda; Malvan; Panchgani (Wroughton, 1913b); Amraoti; Nagpur (Gopalakrishna, 1954); Elephanta; Khandala; Ratnagiri (Brosset, 1962a); Ahmednagar (Joshi, In Molur et al., 2002); Rakeshwadi, Lonavala (Gaikwad, 2007).

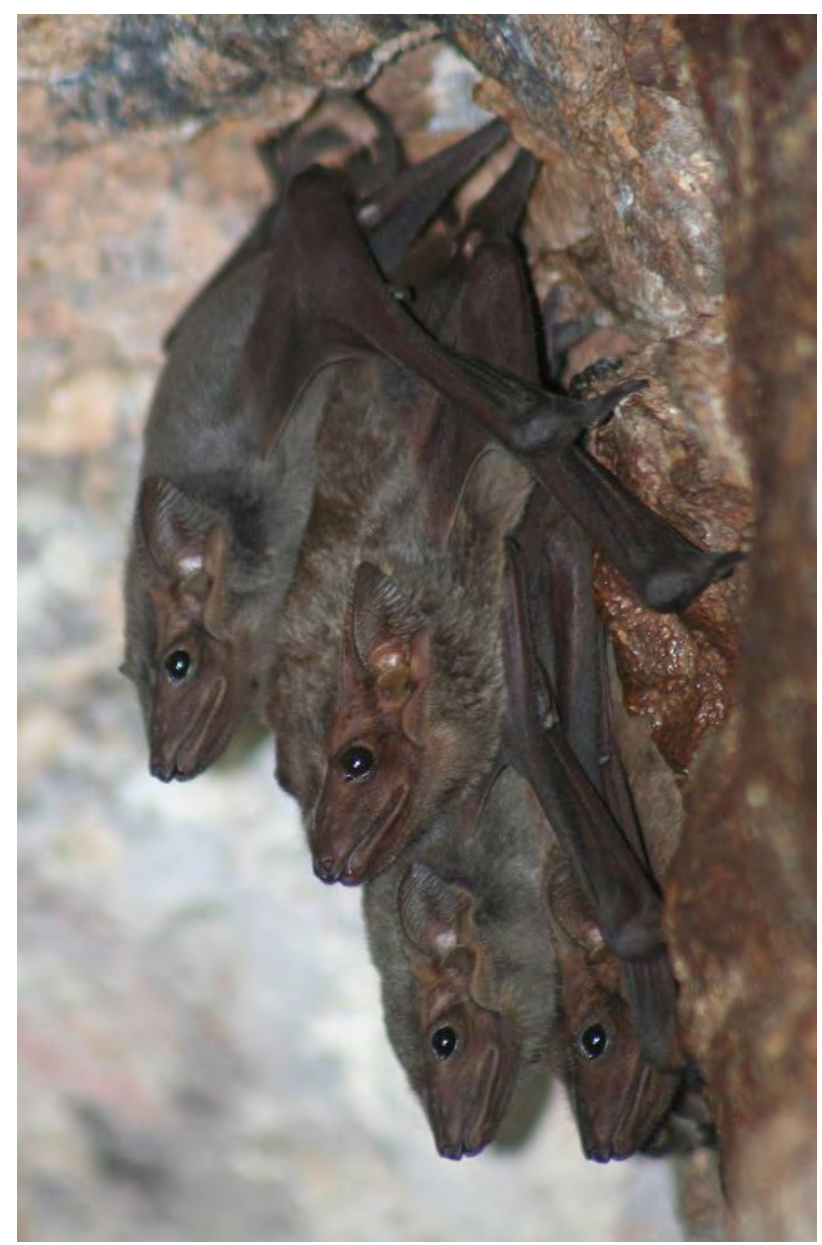

Figure 5: Taphozous longimanus 


\section{Greater False Vampire (Fig. 6) Megaderma lyra}

This bat species is commonly found in the study area. This is a robust species with an average fore arm length 66mm and the upper tooth row averages $11 \mathrm{~mm}$, thus exceeding $M$. spasma considerably in size. The oval ears have fringe of white hairs on the inner margins and the two lobes are joined between one third and half their length. The snout is naked and flesh colored. The lower jaw extends beyond the upper one. The nose leaf is straight and erect, about $10 \mathrm{~mm}$ in height and with a longitudinal median ridge. The base is simple and horizontal, but in M. spasma it is smaller, with convex side and distinctly heart shaped base. Dorsally the pelage is soft, moderately long and mouse colored, while ventrally it is almost white. They were found in various places in study area in groups of 40-200.. In Pothare, the population in a temple backyard was high,. In 2011, at Bhalavani, Mangalvedha due to renovation of an old house, the bat colony was found to be missing. While in Piliv, the fort owner has closed the entrance of the bat colony to remove the smell of bat guano. Osmanabad caves were also found under renovation for promotion as a tourist venue.

Locations: Supe; Daund; Baramati; Piliv-Sangola; Bhalvani-Pandharpur; Indapur; Kurbavi-Malshiras; Bhalvani-Mangalvedha; Pothare-Karmala; Osmanabad caves.

Previous records from Maharashtra: Chinchpali, Bulapur (Wroughton 1913b); Ramane Wadi, Khed (Wroughton, 1916a); Pune (McCann, 1934); Powai lake; Ellora, Aurngabad; Ajanta, Aurngabad; Ghodasgaum; Kanheri, Borivali (Brosset, 1962b); Ratnagiri; Gorthan, Nashik (Sinha, 1970); Bandra (Gopalakrishna \& Badwaik, 1989); Junnar; Panshet; Mahad; Mulshi, Haveli; Bhor Rajewadi; Satara (Gaikwad, 2007).

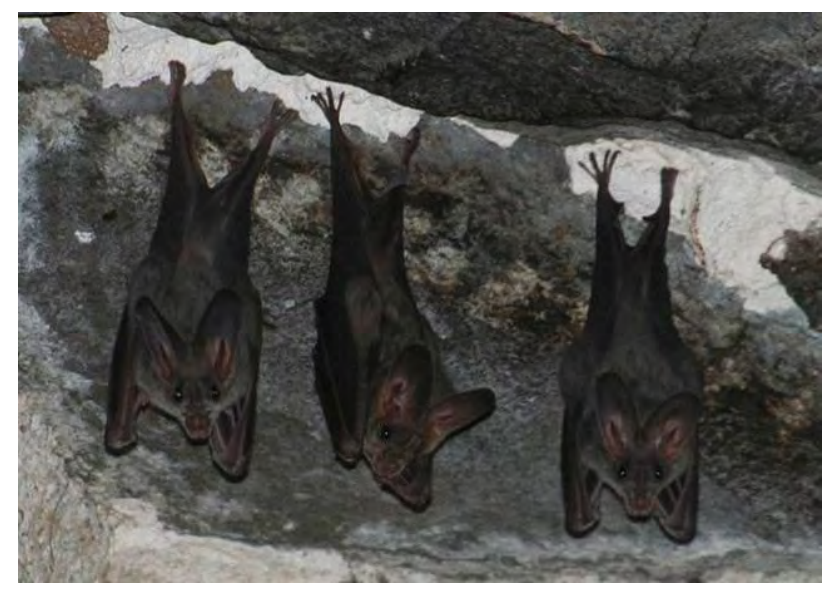

Figure 6: Megaderma lyra

\section{Schneider's Leaf-nosed Bat (Fig. 7) Hipposideros speoris}

The supplementary leaflets are diagnostic for many Hipposideros species. The nose-leaf of $H$. speoris has three supplementary leaflets; the outer one inconspicuous. The median emargination of the anterior leaf-nose is not prominent. The upper edge of the intermediate leaf is concave. The posterior leaf is divided into four cells by three vertical septa and with slightly thickened upper edge. $H$. speoris was found using pilgrimage and historical places with very old temples and constructions. Millions of devotees visit such places and potentially disturb this species. We observed three colonies in different places at Pandharpur town in 2008, which were not seen in 2011, except a place called Kaikadi Maharaj math. Undisturbed areas such as an old mosque in Bhalvani and temple backyard at Pothare were found holding good populations of these bats.

Locations: Bhimanagar; Indapur; Nira Narsingpur; Pothare, Karmala; Bhalavani, Pandharpur; Osmanabad caves; Kurduwadi.

Previous records from Maharashtra: Bhor, Pune; Saswad, Pune; Satara (Hills, 1976); Borivali, kanheri; Elephanta; Alibag; Asgani; Pune (Shivkumara et al., 1984); Chanda (Blanford, 198891) Ranjangaon, Mawal, Pune; Saralgaon, Shirur; Ellora (Bates et al., 1994); Nanded; Chatushrungi cave, Pune; Shivneri Fort, Junnar; Matheran (Gaikwad, 2007).

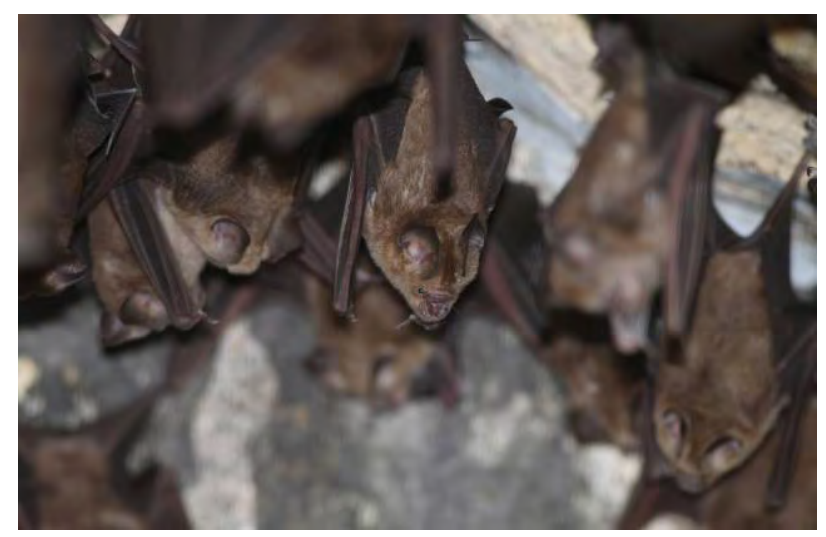

Figure 7: Hipposideros speoris

\section{Egyptian Free-tailed Bat (Fig. 8) Tadarida aegyptiaca}

This species can be identified from its medium size with the fleshy ears separated on the forehead. The tragus is small with a small angular projection. The antitragus is well developed. The skull is moderately long and the braincase is flattened. The median axis running from nasals to lambda is straight. The premaxillae are not co-ossified with palate. The pelage color is clove brown on the 
dorsal side and distinctly pale almost whitish brown on the ventral side. The fur in general is short, soft and extends on the flanks. The membranes, ears and snout are brownish black in color. There is a prominent circular pad with middle depression on the sole of the foot as well as on the base of the thumb. A single individual was found near a temple wall at Dhamangaon, Solapur and a population of near about 60 individuals at an abandoned premise of a temple at Kunthalgiri, Osmanabad district. Its earlier distribution records also suggest that it is not a common species in survey area.

Locations: Dhamangaon, Solapur; Kunthalgiri, Osmanabad.

Previous records from Maharashtra: Aurangabad (Brosset, 1962c); Pune (Brosset, 1962c, Korad \& Yardi, 1998-2001); Khondai, Mulshi (Gaikwad, 2007).

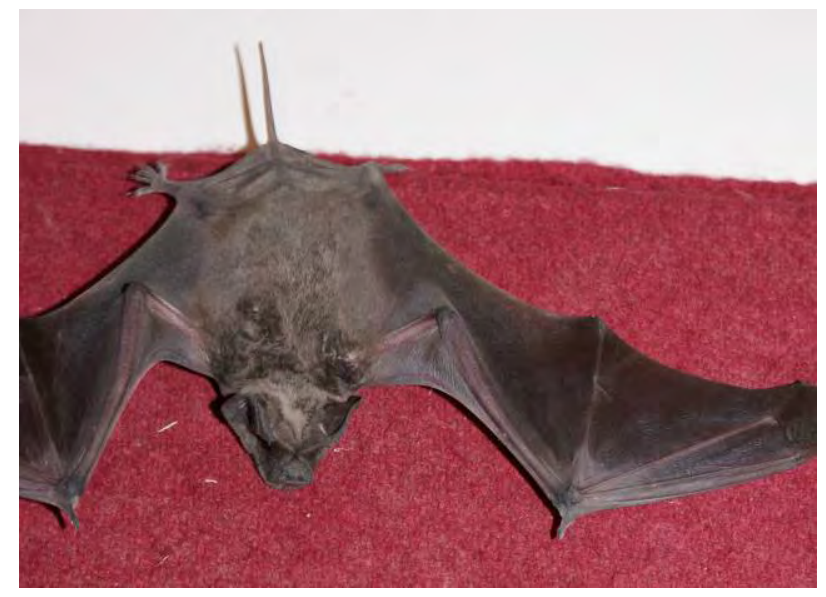

Figure 8: Tadarida aegyptiaca

\section{Asiatic Greater Yellow House Bat (Fig. 9) Scotophilus heathii}

This species is medium-sized with relatively small ears that have a peculiar tragus with the tip projecting forwards. The braincase is narrow and deep. The second upper incisor $\left(\mathrm{I}^{3}\right)$ is absent and the first two upper molars have their main cusps displaced outwards, thus the usual "W" pattern is distorted. It was also one of the cave dwelling bats which was observed in small groups of 1-3 individuals, at five areas such as fort (Naldurga), old spinning mill premises (Solapur), Apsinga (Old monument) and Osmanabad (Buddhist Cave), Dhamangaon (Cerivces of old temple wall).

Locations: Bhima Koregaon; Daund; Nira Narsingpur; Jamb Indapur; Dhamangaon; Solapur.

Previous records from Maharashtra: Nagpur (Khajuria, 1953); Panchgani; (Khajuria, 1953); Thana (Brosset, 1962c); Ajanta (Brosset, 1962c); Bandra; Andheri; Pune; Dhule; Chanda (BMNH); Elephanta (Brosset, 1962c); Bhor; Purandar Fort,
Pune; Deoghar-poladpur; Khed Shivapur; KarjatRaigad (Gaikwad, 2007).

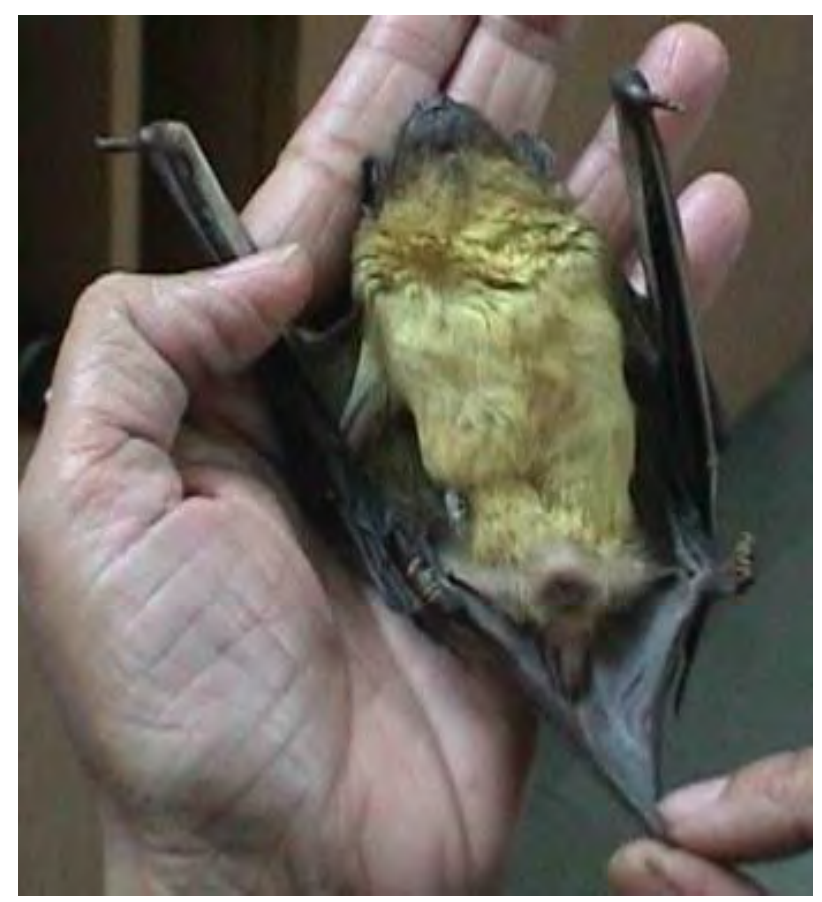

Figure 9: Scotophilus heathii

\section{Kuhl's Pipistrelle (Fig. 10) Pipistrellus kuhlii}

Kuhl's Pipistrelle was recorded only once in a school building in urban area (Korad \& Yardi, 1998-2000). A village boy from Nimblak, brought an injured bat to the first author, who identified the bat as a Kuhl's Pipistrelle from external measurements. The wing membranes are translucent with a distinct white border on the patagium running between the foot and the fifth digit of the wing. The dorsal pelage was dark brown and slightly paler ventrally. The hair roots on the ventral body surface have darker base. The snout, ears and wing membranes are uniformly brown. The tragus is inwardly curved, with a narrow tip and the outer border lacks triangular projection. The medium sized pipistrelle with forearm length $35 \mathrm{~mm}$. It differs from other closely related species in dental peculiarities. $\mathrm{I}^{2}$ is unicuspid, $\mathrm{I}^{3}$ and $\mathrm{Pm}^{2}$ are small, about one half or less in the crown area of $\mathrm{I}^{2}$. The tip of $\mathrm{I}^{3}$ extends slightly beyond the cingulum of $\mathrm{I}^{2}$. The wing membranes are translucent and the most characteristic feature is the presence of distinct white border on the patagium running between the foot and the fifth digit. The dorsal pelage is dark brown and slightly paler ventrally. The hair roots on the ventral body surface have darker base. The snout, ears and wing membranes are uniformly brown. The tragus is inwardly curved, but the tip is narrow and the outer border is 
lacking triangular projection, the presence of which is the peculiarity of $P$. savii. The skull is long, its dorsal profile is almost straight and the lambdoid crest in front of the small triangular area is well developed. $\mathrm{Pm}^{2}$ is displaced inwardly and as a result the upper canine and $\mathrm{pm}^{4}$ seem to be in contact. $\mathrm{Pm}_{2}$ ias smaller, about half of $\mathrm{Pm}_{4}$ in height and crown area.

Location: Nimblak, Satara

Previous records from Maharashtra: Pune (Korad \& Yardi, 1998-2000).

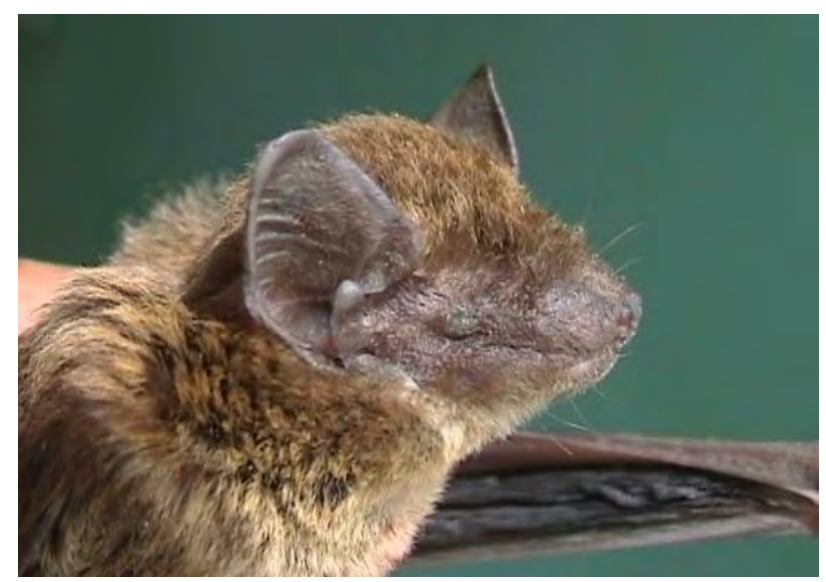

Figure 10: Pipistrellus kuhlii

\section{Savi’s Pipistrelle (Fig. 11) Hypsugo savii}

This is a medium sized bat species with uniformly dark brown long, soft and dense pelage. Ventrally the hair bases are darker, while the tips are pale in color. The snout, ears and wing membranes are uniformly dark brown. The muzzle ias naked and flat. The membranes are translucent. The ear lobes are long and broad at the base. The tip of the ear lobe is rounded. The tragus is long, inwardly curved with a blunt tip. On its outer margin on the lower half, there is a triangular projection. The tail is significantly shorter than the head and body length. Supraorbital tubercles are small while braincase is low, flat and elongate. Basisphenoid pits are lacking. Inner upper incisor $\mathrm{I}^{2}$ is bicuspid. $\mathrm{I}^{3}$ is half or more of height of $\mathrm{I}^{2}$, but similar in crown area. $\mathrm{Pm}^{2}$ is little reduced in crown area, about two thirds of that of $\mathrm{I}^{2}$. Postorbital region, supraorbital region and rostrum are moderately widened. Supraorbital tubercles are small. Braincase is low, flat and elongate. This is a medium sized bat with uniformly dark brown long, silky, soft and dense pelage. Ventrally the hair bases are darker, while the tips are pale in color. The snout, ears and wing membranes are uniformly dark brown. The muzzle is naked and flat. The membranes are translucent. The ear lobes are long and broad at the base. The tip of the ear lobe is rounded. The tragus is long, inwardly curved and with blunt tip. On its outer margin on the lower half, there is a triangular projection. The tail is significantly shorter than the head and body length. Only three earlier records are available from the Maharashtra). Based on our observations we believe that Savi's Pipistrelle is also a common species which has not been studied properly.

Locations: Nimblak, Phaltan, Satara; Kololi, Baramati; Solapur city; Apsinga, Tuljapur; Osmanabad caves.

Previous records from Maharashtra: Pune city (Korad \& Yardi, 1998-2000); Bhaje caves; Mulshi, Pune (Gaikwad, 2007).

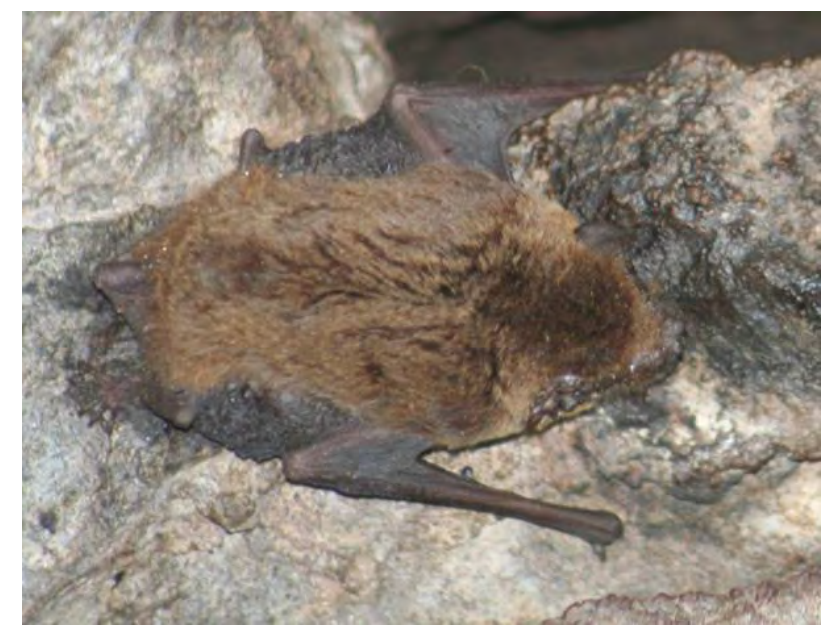

Figure 11: Hypsugo savii

\section{Discussion}

In the present survey 11 bat species were reported from the study area. We believe that the relative humidity and type of habitat are crucial factors for these bats. Large old trees were usually preferred by Pteropus giganteus and small trees such as Ashoka Polyalthia longifolia and other fruit trees were used by Cynopterus spinx. Old buildings, temples, tunnels and forts, which mainly include similar ecological conditions, are highly suitable to cave bats. The disturbed natural habitats have also compelled the cave bats to occupy some manmade constructions as their habitat, where these species were sustained successfully.

It was apparent that all of the above mentioned bat species are much more widely distributed than was previously recorded and populations occur in areas for which only single or scattered records were previously available. Nevertheless, as we observed at several sites, even these species were sensitive to disturbance from people. Rapid developmental activities might still be an important factor for the 
survival of bats in the study area. We therefore recommend further studies to document the current status and distribution of the bats.

\section{Threats}

In the recent study it was observed that many old structures as houses, caves, temples were under renovation. Road ways construction, township projects, tourism, development of agricultural land removing natural vegetation etc. are also affecting bat fauna. Some mortality is due to trapping in nylon nets put around fruit crops such as vineyards. Thus it is important to study the impact of changing habitat and loss of suitable areas on survival of bats in the region (Jones et al., 2009) with the help of a continuous bat monitoring programme. The uncontrolled use of chemical fertilizers and insecticides may have an effect on the food source of insectivorous bats. Pesticides may pose some detrimental effects on bat populations as seen in Clark et al. (1983). Extermination of colonies by pest control operators and Public Health Departments has also been responsible for the elimination of many bats in urban areas. We observed that availability of natural water was also one of the influential factors for distribution of bat species in the study area.

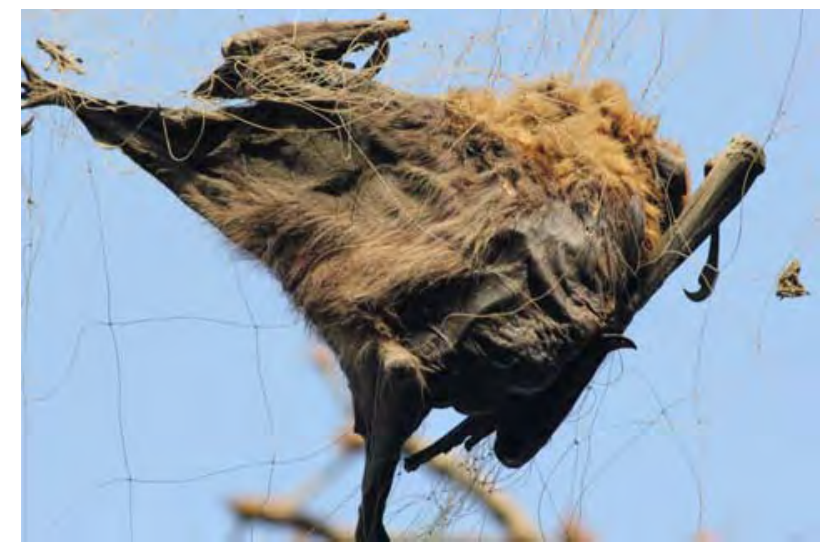

Figure 12: A bat trapped in nylon net at an orchard.

\section{Conservation recommendations}

Forts, temples, devrai or sacred groves were found as important habitats for bats and should remain untouched by the activities such as renovation. Care needs to taken to protect the natural roosting habitats.

Survey and monitoring of the bat colonies from study area should be encouraged with help of volunteers and local NGOs.

Under the process of afforestation, indigenous plant species should be preferred over exotic plants.
Ecosystem services provided by the bats should be studied and conservation of bats should be promoted as the important bio-indicators (Jones et al., 2009).

\section{Acknowledgements}

We are thankful to Somnath, Shivaji Narwade, Divya Varier, Mahesh Gadkar, Bharat Cheda, Vaibhav Vanjari and Rameshwar Fugare for their support during the field surveys and data compilation. We are also thankful to Matthew Struebig, Judith Eger and an anonymous reviewer for reviewing the manuscript.

\section{Literature cited}

Bastawade, A. D. and A. S. Mahabal, 1976. Some behavioral aspects of the Indian flying fox Pteropus giganteus giganteus. Bio-Vigyanam, 2 (2): 209-212.

Bates, P. J. J. and D. L. Harrison, 1997. Bats of the Indian subcontinent. Harrison Zoological Museum Publication, Bowerwood House, St. Botolph's Road, Sevenoaks, Kent TN 13 3AQ, England:

Bates, P. J. J., D. L. Harrison and M. Muni, 1994. The bats of Western India. Part 3: Journal of Bombay Natural History. Society, 91: 360-380.

Blanford, W. T., 1888-91. The Fauna of British India,Mammalia. Taylor and Francis, London: 617.

Brosset, A., 1962a. The bats of Central and Western India. Part I. Journal of Bombay Natural History. Society, 59: 1- 57.

Brosset, A., 1962b. The bats of Central and Western India. Part II. Journal of Bombay Natural History. Society, 59: 583-624.

Brosset, A.,1962c. The bats of Central and Western India. Part III. Journal of Bombay Natural History. Society, 59: 707-746.

Brosset, A., 1962d. The bats of Central and Western India. Part IV. Journal of Bombay Natural History Society, 60: 337- 355.

Champion, H. G. and S. K. Seth, 1968. The forest types of India. The manager of publications. Delhi:

Clark, D. R., R. Clawson and C. Stafford, 1983. Gray bats killed by dieldrin at two additional Missouri caves: Aquatic invertebrates found dead. Bulletin of Environmental Contamination and Toxicology, 30: 214-218. 
Das, P. K and Y. P. Sinha, 1971. Taxonomic and biological notes on the Shortnosed Fruit Bat, Cynopterus sphinx (Vahl) from West Bengal. Proceedings zoological Society, Calcutta, 24: 157162

Davison, G. W. H. and A. Zubaid, 1992. Food habits of the lesser false vampire, Megaderma spasma, from Kunla Lompat, Peninsular Malaysia. Zeitschrift Saugetierk, 57 (5): 310-332.

Eckrich, M. and G. Neuweiler, 1988. Food habits of the sympatric insectivorous bat Rhinolophus rouxi and Hipposideros lankadiva from Sri Lanka. Journal of Zoology, 215: 729-737.

Gaikwad, M. C., 2007. Study on diversity and habitat preference of cave bats (Chiroptera) in the central Western Ghats of Maharashtra. Ph.D. thesis submitted to the University of Pune, through Department of Zoology, Fergusson College, Pune:

Gopalakrishna, A., 1954. Breeding habits of the Indian sheath tailed bat Taphozous longimanus (Hardwicke). Current Science, 23: 60-61.

Gopalakrishna, A. and N. Badwaik, 1989. Breeding habits and association phenomena in some Indian bats. Part 12. Megaderma lyra (Geoffroy) (Megadermatidae) at different latitudes. Journal of Bombay Natural History Society, 86 (1): 42-45.

Hallam, T. G., A. Raghavan, H. Kolli, D. T. Dimitrov, P. Federico, Hairong Qi, G. F. McCracken, M. Betke, J. K. Westbrook, K. Kennard and T. H. Kunz, 2010. Dense and sparse aggregations in complex motion: Video coupled with simulation modeling. Ecological Complexity, 7: 69-75.

Hill, J. E., 1976. Further records of Myotis peshwa (Thomas 1915) (Chiroptera Vespertilionidae) from the Indian peninsula. Journal of Bombay Natural History Society, 73 (3): 433-437.

Hill, J. E. and J. D. Smith, 1984. Bats: A Natural history. British Museum of Natural History: 243.

Jones, G., D. S. Jacobs, T. H. Kunz, M. R. Willig and P. A. Racey , 2009. Carpe Noctem: the importance of bats as bioindicators. Endangered Species Research, 8: 93-115.

Khajuria, H., 1953. Taxonomic studies on some Indian Chiroptera. Records Indian Museum, 50: 113128.
Korad, V. S. and K. D. Yardi, 1998-2001. Ecological study of bats in Pune. UGC minor project:

Korad, V. S. and M. C. Gaikwad, 2006. Study of distribution of water bats (Genus Myotis ) in the part of Northern Western Ghats of India. Proceedings of $17^{\text {th }}$ All India Congress of Zoology:

Korad, V. S., R. Raut and K. D. Yardi, 2007. Diversity and distribution of bats in the Western Ghats of India. Zoos Print Journal, 22 (7): 2752-2758.

Kunz, T. H., 1982. Roosting ecology of bats. In. Ecology of Bats, Kunz, T. H. (ed.). Plenum press, New York: 1-55

McCann, C., 1934. Notes on the Flying-Fox (Pteropus giganteus Brunn.). Journal of Bombay Natural History Society, 37: 143-149

Mickleburgh, S. P., A. M. Hutson and P. A. Racey, 2002. A review of the global conservation status of bats. Oryx, 6 (1): 18-34.

Molur, S., G. C. Marimuthu, Srinivasulu, S. Mistry, A. M. Hutson, P. J. J. Bates, S. Walker, K. Padma Priya and A. R. Binu Priya, 2002. Status of South Asian Chiroptera: Conservation Assessment and Management Plan (C.A.M.P) Workshop Report. Zoo Outreach Organization, CBSG South Asia and WILD, Coimbatore, India: 141.

Moghe, M. A., 1951. Development and placentation of the Indian Fruit bat, Pteropus giganteus giganteus (BruIU1ich) Proceedings Zoological. Society of London, 121: 703-721.

Pierson, E. D. and W. E. Rainey, 1998. Distribution, Habitat Associations, Status, and Survey Methodologies for Three Molossid Bat Species, (Eumops perotis, Nyctinomops femorosaccus, Nyctinomops macrotis) and the Vespertilionid (Euderma maculatum). Final report, California Department of Fish and Game Wildlife Management Division, Bird and Mammal Conservation Program: 62.

Rainey, W. E. and E. D. Pierson, 1992. Distribution of Pacific Island flying foxes, Proceedings of the Pacific Island Flying fox Conservation Conference, USFWS, Biology Report No. 90, Washington, D. C.: 111-121.

Shivkumara S., N., P. M. Reddy and M. Kameswari, 1984. Host-parasite relationship: posthelminth infection muscle protein changes in bat Hipposideros speoris. Current Science. 53 (4): 207-208. 
Sinha, Y. P., 1970. Taxonomic notes on some Indian bats. Mammalia, 34: 81-92.

Srinivasulu, C., P. A. Racey and S. Mistry, 2010. A key to the bats (Mammalia: Chiroptera) of South Asia. Journal of Threatened Taxa, 2 (7): 1001-1076.

Swift, S. M., 1980. Activity patterns of pipistrelle bats (Pipistrellus) in north-east Scotland. Journal of Zoology, 190: 285-295.

Wroughton, R. C., 1912. Report No. 1: East Khandesh. Bombay Natural History Society's Mammal Survey of India. Journal of Bombay Natural History Society, 21 (2): 391-410.

Wroughton, R. C., 1913a. Report No 6. Kanara Central Provinces. Bombay Natural History Society's Mammal Survey of India. Journal of Bombay Natural History Society, 22 (1): 29-44.

Wroughton, R. C., 1913b. Report No 7. Central Provinces. Bombay Natural History Society's Mammal Survey of India. Journal of Bombay Natural History Society, 22 (1): 45-58.

Wroughton, R. C., 1913c. Report No 8. (with K.V. Ryley) Vijayanagar- Central Provinces. Bombay Natural History Society's Mammal Survey of India. Journal of Bombay Natural History Society, 22 (1): 58-66.

Wroughton, R. C., 1916a. Report No 20. Chindwin River. Bombay Natural History Society's Mammal Survey of India, Burma and Ceylon. Journal of Bombay Natural History Society, 24: 291-309.

Wroughton, R. C., 1916b. Report No 21. Gwalior. Bombay-Natural History Society's Mammal Survey of India, Burma and Ceylon. Journal of Bombay Natural History Society, 24: 309-310.

Wroughton, R. C., 1916c. Report No 22. Koyna Valley, Bombay Natural History Society's Mammal Survey of India, Burma and Ceylon. Journal of Bombay Natural History Society, 24: 311-316.

Wroughton, R. C. and W. M. Davidson, 1920a. Report No. 30: Dekhan, Poona District. Journal of Bombay Natural History Society, 26: 1025-1030. 


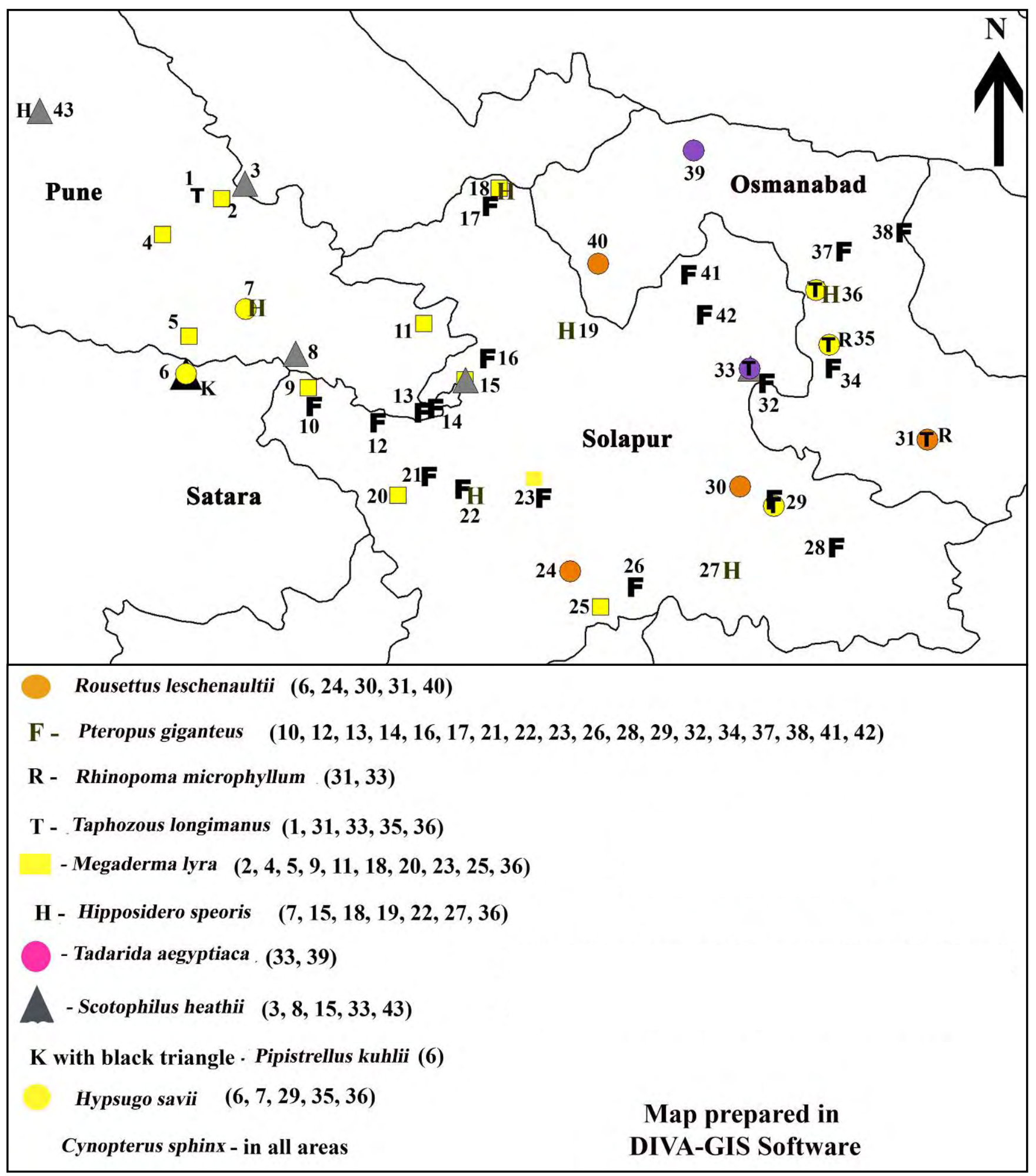

Figure 13: Distribution of bats in South-West region of Deccan, Maharashtra - India: 1. Patas; 2. Daund; 3. Girim; 4. Supe; 5. Baramati; 6. Nimblak; 7. Bhimanagar; 8. Jamb; 9. Kurbavi; 10. Natepute; 11. Indapur; 12. Malshiras; 13. Akluj; 14. Malinagar; 15. Niranarsinghpur; 16. Temburni; 17. Karnala; 18. Pothare; 19. Kurduwadi; 20. Piliv; 21. Maloli; 22. Pandharpur; 23. Bhalvani (pandharpur); 24. Sangola road (mangalvedha); 25. Bhalvani (mangalvedha); 26. Mangalvedha; 27. Mandrup; 28. Chincholi-South Solapur; 29. Solapur city; 30. Kegaon-hiraj road; 31. Naldurga Fort; 32. Kati; 33. Dhamangaon; 34. Sindfal; 35. Aapsinga; 36. Osmanabad city; 37. Kini; 38. Jagji; 39. Kunthalgiri; 40. Paranda; 41. Barshi; 42. Pangaon; 43. Bhimakoregaon. 